\title{
Anne Baba Olma Farkındalığı Gelişiminde Yaratıcı Dramanın Yöntem Olarak Kullanılması
}

\author{
Ö. Özlem GÖKBULUT.
}

Milli Ĕgitim Bakanlı̆̆l

\begin{abstract}
Özet
Bu çalışmanın amacl; oyun, ögrenme, eğitim, özgüven, ödül, ceza, tüketim, bireysel özellikler vd. gibi kavramlardan hareketle yaratıcı drama ile çocukluğun temel değerlerini anlamak ve yapılan "farkındalık" geliş̧imi çalışması ile okul çalışanlarl, öğretmenler ve velilerin arasında sağlıklı bir okul aile iletişimi sağlamaktır. Bu amaca yönelik olarak 2004-2005 Ĕ̆itim Öğretim Yılının Bahar Döneminde MEB'e bă̆ll bağımsı bir anaokuluna devam eden 120 çocuğun anne babasl, anaokulu'nun öğretmenleri ve çalışanlar olmakla birlikte tüm anne babalar, okulöncesi eğitimi ögretmenleri projenin temel hedef kitlesi olarak belirlenmiştir. Çalışma, alan uzmanlarının rehberlik ettiği bilgi, duygu ve deneyimlerin 9 oturumda paylaşıldığ bir ön hazırlık bölümü ile okul yöneticisi/drama liderinin rehberlik ettiği 8 oturumda (24 saat), ele alınan konuların yaratıcı drama yöntemiyle işlendiği uygulama bölümünden oluşmuştur. Veri toplama araçlarından edinilen bulgulara göre çalışmanın genel amacına ulaştı̆̆ı, davranış değişikliği açısından katılımcılarda farkındalık yaratıldı̆̆ söylenebilir.
\end{abstract}

Anahtar sözcükler: Çocuk, çocukluğu ve yetişkinliği anlamak, yaratıcı drama, okul aile iletiş̧imi

\begin{abstract}
The purpose of this study is to comprehend the fundamental values of childhood with the help of creative drama by taking into consideration the concepts like plays, learning, education, self efficacy, promotion, punishment, consumption, and individual characteristics. Another purpose is to establish an healthy connection between the school and family by carrying out a study on the development of "awareness". For this purpose, the target group was determined as the parents of 120 students who are in a preschool of Ministry of Education, the teachers and other personel of this school, all parents, and the kindergarden teachers. This study consisted of two parts; first part can be named as preparation part in which the feelings and experiences of the participants were shared with the help of field experts. This part had 9 sessions. The second part is the implementation of creative drama activities taking 8 sessions (24 hours). According to the findings, it can be claimed that this study reached its purpose since during implementation an awareness occured in the participants.
\end{abstract}

Keywords: Child, understanding the childhood and the adulthood, creative drama, the communication between the school and the family.

·Bil.Uzm., Anaokulu Öğretmeni, E-posta: ooozlem@mynet.com 


\section{Giriş}

Geleceğin yetişkini ve toplumun belirleyicisi olan çocuklar, okulöncesi dönemde gelişimlerinin en hızlı olduğu ve kişilik gelişimlerinin büyük oranda tamamlandığ 1 bir süreç yaşarlar. $\mathrm{Bu}$ sürecin sağlıklı geçirilmesi, yaratıc1, özgüvenli, erdemli, sorgulayan bireylerin yetişmesini ve bu bireylerin oluşturacağı toplumsal yapıyı da doğrudan etkilemektedir. Bunun için çocuğun gelişim özelliklerinin bilinmesi, tanınması, çocuk ve çocukluk kavramlarının tam olarak anlaşılması gerekmektedir.

Günümüzde çocuklar, anne baba, eğitim kurumları ve yakın çevresinin yaklaşımları nedeniyle davranışları, alışkanlıkları, giyimleri, kendilerini ifade biçimleri ve değerleri ile yetişkinlere benzemeye ve çocukların doğasında olan özelliklerini kaybetmeye başlamıştır. Sağlıklı nesillerin yetiştirilebilmesi için öncelikle ana baba ve eğitim kurumları çocuğa kendisinin öğrenebileceği ortamları hazırlayarak, gerçek anlamıyla çocukları birey olarak kabul ederek, ona kendini ifade etme ve kendi kararlarını alma firsat1 vererek, özgüvenini destekleyerek rehberlik etmelidir. Çocuklara rehberlik edebilmek, yaşamda yeni yollar gösterebilmek için öncelikle onları tanımalı, gelişim özelliklerini bilmeli, çocuğu ve çocukluğu anlamalıdır. Tüm bunları okul aile iletişimini, etkileşimini en üst noktaya taşıyarak yapmalıdır. Eğer okul, aile ve çocuğun etkileşimde olduğu diğer bireyler aynı yaklaşımla çocuğun yanında yer almazlar ise çocuk çatışma yaşayacak ve gelişim sürecini sağlıklı tamamlayamayacaktır.

Çocukların sağlıklı olarak bu süreci geçirmeleri, doğasında var olan olumlu özellikleri, değerleri koruyabilmeleri ve çocukluğun yok olmaması için "çocuk" ve "çocukluğun" anlaşılması ve çocuğa saygı duyulması gerekmektedir. Çocuk, kuramlar geliştiren, veriler elde eden ve hipotez geliştiren, kendi yolları olan bireydir. Çocuk bilgiyi üretme ve yaratma kapasitesine, duygusal, sosyal, zihinsel, fiziksel yönden birçok farklı kaynağa sahip olan varlıktır (Hamurcu ve Ekinci, 2004, s.16).

Çağdaş insanın temel sorunlarından biri, belki de en önemlisi başkaları tarafından iyi anlaşılmamaktır. Anlaşıldığını hisseden birey rahatlar, huzur duyar. Kendisini olduğu gibi ortaya koyan birey kendiliğindenliğini ve yaratıcılığını kullanır (Okvuran, 1995, s.188). Kendisi olan, bu özelliğini kaybetmeyen, yaratıcı, özgüvenli çocuklar yetiştirebilmek için çocuğu ve çocukluğu anlamak gerekmektedir.

Değişimin her alanda ve yaşam biçiminde etkisini net bir biçimde gösterdiği günümüzde çocukluk kavramı da bu değişimden etkilenmekte ve farklı bir boyuta doğru gitmektedir. Okulöncesi kurumlarından üniversitelere kadar tüm eğitim kurumları çocukları eğitmek için yoğun çaba harcamalarına karşın çocuklarda onaylanmayan değerlerin ve davranış biçimlerinin oluştuğu ve yetişkin olduklarında da bu yapılarını sürdürdükleri gözlenmektedir. $\mathrm{Bu}$ yapının belirginleşmeyen kimliklere, oturmamış değerlere ve eğitim, sağlık, hukuk gibi ülke işleyişindeki temel sistemlere yansıyacağı düşünülmektedir.

\section{Anne Baba ve Çocuk İlişkisi}

Gordon, "Anne - babalar çocuklarının ilk ve çoğunlukla en etkili öğretmenleridir" demektedir. Bu görüşten hareketle, çocuğun 0-6 yaş döneminde, anne ve babalar hem çocuklarının ilk öğretmenleri, hem de onlara en yakın olan insanlardır. Bir insanın kişiliğinin temelinin 0-6 yaş döneminde atıldığ 1 göz önüne alındığında eğitici ve geliştirici kimliğin belirlenmesinde anne ve babanın rolü önem taşımaktadır (Şatır, 1996, s.3). 
Öz'e (2003, s.18) göre, anne baba için çocuğunu anlamada en büyük engel, çocuklarını kendilerinin birer kopyası olarak düşünmeleridir. "Benim çocuğum" söyleminin ardında yatan gerçek "Benim çocuğum bana benzer" düşüncesi olabilir. Çocuğun varlığını kabul etmek, birey olduğunun da kabulü anlamına gelmekte dolayısıyla kendi kararları konusunda söz sahibi olduğunu bilmeyi ve ona göre davranmayı da gerektirmektedir. Anne - babalardan sadece birinin bunu kabul etmesi hiçbir anlam taşımamakta, farklı yaklaşımlardan dolayı çocuğa çatışma yaşatmaktadır. Anne ve babanın günlük yaşamda fark etmeden sergilediği farklı tutumları çocuklar sanılandan çok daha kısa sürede algilar ve bundan etkilenir. Bu nedenle ana babalar çocuklarının kişilik gelişimini olumsuz anlamda etkilememek için çocuklarına aynı doğruları benimseyerek yaklaşmalıdır. Anne baba aynı yaklaşımla çocuğa yaklaşırken ona bir tür "yaşam reçetesi” sunmak, her türlü ayrıntısını belirlemek, düzenlemek ve denetlemek yerine seçenekler sunarak kendi kararlarını vermesini sağlamak, özdenetimini, özsaygısını ve özgüvenini geliştirmek konusunda rehberlik etmelidir.

\section{Okul Aile İletişimi}

Okulöncesi dönemde çocuğun sağlıklı bir birey olabilmesi ve iyi yetişebilmesi için okulöncesi eğitim alması önemlidir. Okulöncesi eğitim de çocuğa öğrenme ortamları ve eğitim programları hazırlarken çocukları anlamayı ön plana almalıdırlar. Çocuğu anlamak için de çocuğu ailesinden ayrı düşünmek söz konusu değildir. $\mathrm{Bu}$ nedenle günümüzde okul sadece çocukların eğitimini hedefleyen kurum kimliğinden çıkmalıdır. Hangi yaşta olursa olsun çocuk, ailesi ile birlikte düşünülmeli ve çocuğa öyle davranılmalıdır. Ancak öyle hedeflenen amaçlara ve başarıya ulaşılabilir. Okul ve ailenin değerler açısından uzlaşması için bir arada olacak bireylerin farkındalığının artırılması, mümkün olduğunca çok katılımcı olmaları için gerekli programların düzenlenmesi, çocukluğa ilişkin tüm kavramların ve değerlerin tartışmaya açılarak sorgulanması ve irdelenmesi gereklidir.

"Çocukluğu anlamak" kavramının anne baba, öğretmen, okul çalışanları ve gönüllü olan herkesle irdelenip, sorgulanıp anlamının bulunmaya çalışıldığı ve her yaşta, her türlü eğitim düzeyinde öğrenme ilkesinin söz konusu olduğu bu projede öğrenmenin gerçekleşmesi için diğer öğrenme yöntemleri ile birlikte, aktif öğrenme yöntemlerinden birisi olan yaratıcı drama yöntemi de kullanılmıştır.

\section{Yaratıcı Drama}

Yaratıcı drama önemli bir öğrenme yolu olduğu gibi insanın bireysel ve toplumsal sorunlar üzerinde düşünmesine yardım etmenin de bir yoludur. Drama aracılığıyla olaylar ve durumlarla bunların arasındaki bağlantılar kolayca öğrenilebilir (Üstündağ, 2002, s.200).

Çocukluğu anlamak ve doğru değerlerini koruyabilmek için yetişkinlerin değerlerini gözden geçirmesi, bunu yaparken etkileşimde olduğu insanların deneyimlerinden ve bilgilerinden faydalanması gerekir. Yaşam içinde özellikle çocukla iletişim ve etkileşim halindeyken, çocukluğu anlamak konusunun tartışılması, davranışların gözden geçirilmesi ve diğer yetişkinlerin yaklaşımlarının paylaşılması doğru olmayacağından, kurgusal bir ortam sunan ve gerçekle bağını koparmayan bir yöntem olan yaratıcı dramanın bu konuda işe yarayacağı düşünülmektedir.

Yaratıcı Drama yaşantıları belli aşamaları izlemek durumundadır. Bu aşamalar yine liderin yapacağı çalışmaya göre biçimlendirilebilir, değiştirilebilir. Bu aşamalar:

I- Hazırlık - Isınma Çalışmaları 
II- Canlandırma

III- Değerlendirme-Tartışma

"Çocukluğu ve Büyüklüğü Anlamak - Anne Baba Farkındalığı Gelişiminde Yaratıcı Drama Yönteminin Kullanılması" projesinde yukarıda yer alan basamaklar izlenmiştir (Adıgüzel, 1994; San, 1989).

\section{Çalışmanın Önemi}

Çocuğun yaşamında yer alan ana baba, öğretmen, okul çalışanları ve etkileşimde olduğu diğer bireyler ile birlikte çocukluğun günümüzde bulunduğu durumu tartışmak, çocuk ve çocukluğu anlamak ve bu konuda yaratıcı drama ile diğer öğrenme yöntemlerini kullanarak farkındalık gelişimini sağlamak amacıyla eğitim kurumları içinde en önemlilerinden biri ve çocuğun yaşamında en belirleyici olduğu düşünülen bir okulöncesi kurumunda bu çalışma tasarlanmış ve uygulanmıştır.

\section{Çalışmanın Amacı}

Oyun, öğrenme, eğitim, özgüven, ödül, ceza, tüketim, bireysel özellikler vd. gibi kavramlardan hareketle yaratıcı drama ile çocuğu, çocukluğu, çocukluğun temel değerlerini anlamak ve yapılan "farkındalık" gelişimi çalışması ile okul çalışanları, öğretmenleri ve velilerin arasında sağlıklı bir okul aile iletişimi ile iş birliği sağlamaktır.

\section{Örneklem}

Ankara İli Etimesgut İlçesinde Milli Eğitim Bakanlığı'nın bağımsız bir anaokuluna devam eden 120 çocuğun anne babası, anaokulunun öğretmenleri projenin temel hedef kitlesi olarak belirlenmiştir. Çalışmada toplam 97 kişiye ulaşılmıştır. Yaratıcı drama çalışmaları ise, 15 kişi sürekli olarak katılmak üzere, 20 ile 25 arasında değişen katılımcılar ile yürütülmüştür. $\mathrm{Bu}$ bağlamda atölye çalışmalarının uygulandığı örneklem sayısı ortalama 15 kişidir. Çalışmaya katılım gönüllülük esasına dayanmaktadır.

\section{Çalıșmanın Yaklașım, Yöntem ve Teknikleri}

Projede alan uzmanları, uygulayıcı ve tüm katılımcıların öğrenen olarak kabul edildiği bir çalışma yapılmıştır. Projenin birinci bölümü olan duygu, düşünce ve paylaşım toplantılarında anlatım ve tartışma yöntemleri, soru-yanıt, grup çalışması, rol oynama teknikleri kullanılmıştır.

Projenin ikinci bölümü olan yaratıcı drama çalışmalarında, rol oynama, doğaçlama, pandomim, rol içinde yazma, fotoğraf anı, donuk imge, iç ses, tartışma, çağrışım zinciri teknikleri kullanılmıştır.

\section{Çalışmanın Değerlendirilmesi}

Farkındalık gelişimi çalışması olarak yapılan projede bu süreci destekleyeceği düşünülen ve değerlendirmede kullanılmak üzere farklı çalışmalar da yapılmıştır. Bunlar; iki ana başlık altında toplanmıştır. Birincisi bilgi toplamaya yönelik çalışmalar, ikincisi projeye katkı getireceği düşünülen yan çalışmalardır.

Projede katılımc1 grubun net olarak belirlenememesi, isteyenlerin sürecin herhangi bir yerinden dahil olmalarının söz konusu olması ve gönüllüğe dayalı bir çalışma olması nedeniyle değerlendirmeye yönelik yapılandırılmış çalışmalar sadece okul personeline uygulanmıştır. Diğer katılımcılardan dönüt almak için açık uçlu, onların isteğine bırakılmış alternatif çalışmalar yapılmıştır.

1.Bilgi Toplamaya Yönelik Çalışmalar

a. Bilgi Duygu Paylaşım Toplantıları Değerlendirme Formu: Bu toplantılarda katılımcilara değerlendirme formu dağıtılmıştır. Bu form toplantı hakkında beklentileriniz ve toplantı sonrası görüşleriniz olmak üzere iki bölümden oluşmuştur. 
b. Okul Personeli Ön Değerlendirme Formu: Okul personelinin proje başlamadan yapılan projenin kısa tanıtım toplantısından sonra beş sorudan oluşan ön değerlendirme formunu doldurması sağlanmıştır. $\mathrm{Bu}$ formda aşağıdaki sorulara yer verilmiştir.

1. Proje hakkındaki görüşleriniz, sorularınız, eleştirileriniz ve katkılarınız

2. Veliler hakkındaki görüşler

3.Çocukluğun değerleri (Çocuklar birbirinden ve büyüklerden ne bekler?)

4.Büyüklüğün değerleri (Büyükler birbirlerinden ve çocuklardan ne bekler?)

5. Proje sonuçlarına dair beklentiler

c. Okul Personeli Son Değerlendirme Formu: Okul personeline proje tamamlandiktan sonra aşağıdaki içerikten oluşan son değerlendirme formu verilmiş ve doldurmaları sağlanmıştır.

1. Proje hakkındaki öneri ve eleştirileriniz

2. Veliler hakkındaki görüşleriniz

3.Çocukluğun değerleri (Çocuklar birbirinden ve büyüklerden ne bekler?)

4.Büyüklüğün değerleri (Büyükler birbirlerinden ve çocuklardan ne bekler?)

5.Proje sonuçları (Özellikle kendinizde değişikliği değerlendirmeniz bekleniyor)

d.Yaratıcı Drama Çalışmalarından Beklentilerle İlgili Form: Yaratıcı drama çalışmalarına başlamadan katılımcılara yaratıcı drama çalışmalarından beklentilerinin sorulduğu bir form doldurulmuştur.

a. Açık Defter

b. Proje Yayınları

c. Çocuk Değişimi

d. Anne Babanın Öğrenmeye Aktif Katılımı Seçki

e.Yaratıcı Drama Çalışmalarından Hazırlanan

\section{Sonuç, Yorum ve Öneriler}

Projenin temel amacı "çocukluğu anlamak" konusunun anaokulu velileri, öğretmenleri, çalışanları, alan uzmanları ve alanla etkileşimde olanlar başta olmak üzere toplumsal sorunlarla ilgilenen tüm bireylerle irdelenip, karşılaştırılıp, gözden geçirilip, içselleştirilerek çocukluğun özü ve temel değerlerinin anlaşılması olarak saptanmıştır.

İkinci amaç ise çocukluğu anlamak konusunda yapılan farkındalık gelişimi çalışmasının okul çalışanları, öğretmenleri ve velilerin ortak katılımıyla yapılıp sağlıklı bir okul aile iletişimi sağlayarak okul ve aile arasındaki ortak dili oluşturmak olarak belirlenmiştir.

Buradan da anlaşılacağı gibi çocukluk kavramının algılanış biçimi ve okul aile iletişimi sorun olarak belirlenmiş, sorunun çözümü için öncüllerden birisi olan "çocukluğu anlamak" kavramı üzerinde durulmuştur. Bir şeyi, durumu ya da kimseyi anlamak için ön koşul bireyin kendini tanıması ve anlamasıdır. Yaratıcı drama ve duygu düşünce paylaşım toplantılarının amaçlarından birisi de bu olmuştur. Değerlendirme çalışmalarından çıkarılan sonuçlar bu amaca ulaşıldığını göstermektedir. Her ne kadar konu başlığ1 çocukluğu anlamak olsa bile, katılımcıların büyük bir kısmı kendilerinde olan değişiklikleri ve kendi yaşamlarına dair izlerden, yaşantılardan söz etmişlerdir.

Katılımcılarda görülen değişiklikler süreç içinde net çizgilerle ayrılmamakla birlikte genel olarak kendileriyle ilgili değerlendirme ve sorgulamalardan sonra çocuğuyla veya çocuklarla olan ilişkilerini doğrularını ve yanlışlarını gözden geçirmişlerdir. Bir tür yüzleşmeyi gerektiren bu süreç sonunda, büyük bir açıklıkla yaşadıklarını ifade etmişlerdir.

Değerlendirme ve bilgi toplama amaçlı yapılan tüm çalışmalarda ve yazılarda katılımcılar proje içinde yer alan amaç ve kazanımların gerçekleştiğine dair yazılı ve sözlü ifadelerde bulunmuşlardır. Ayrıca katılımcıların hepsi sürecin tamamından memnun kaldıklarını, süreç boyunca kendilerini iyi hissettiklerini ifade etmişler, çalışmaların süresinin uzun ve akşam olmasıyla ilgili birkaç kişiden gelen eleştiri dışında olumsuz bir düşünce ya da duygu belirtmemişlerdir. 
$\mathrm{Bu}$ sonuçların projenin amacına ulaşması noktasında önemli veriler olmakla birlikte asıl olanın düşünce ve ifade sinırlılığında kalmayıp davranışa dönüşmesi olduğu göz ard1 edilmemelidir. $\mathrm{Bu}$ açıdan bakıldığında somut olarak gözlemlenen durumlar şunlardır: Okul personelinin daha önce kendi arasında yaşadı̆̆ küçük çatışmaların azaldı̆̆g, ekip çalışması gerektiren her türlü durumda başarll süreçler

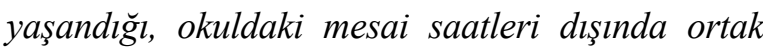
paylaşımların arttığı, yardımlaşma ve paylaşma konusunda belirgin olarak gelişmelerin olduğu, Özellikle projeye katılan velilerin okulla diyaloglarının arttığ ; katılımc velilerin okulun problemleriyle yakindan ilgilendiği, okul bahçesini düzenlemek için "girişimci grup" olarak isimlendirdikleri bir grup velinin birleşerek bahçe düzenlemesini yaptırdı̆̆ı; projeden önce de yapılan "velinin aktif katılim programi"na projeden sonra daha fazla talep olduğu; daha önce okula giriş çıkıslarda, çocuk alıp verirken yaşanan diyalogların biçiminin olumsuzdan olumluya doğru değişim gösterdiği; öğretmenlerle veliler arasinda yaşanan ama ifade edilemeyen iletişim sorununun özellikle ögretmenlerin çabasıyla ve hoşgörülü yaklaşımıyla aşıldığı; velilerin çocukların öz bakım ihtiyaçlarına dair sıkça sordukları "Yedi mi? Uyudu mu? Terledi mi?" sorulartnin belirgin bir biçimde azaldiğg; projeye istedikleri halde özel nedenlerinden dolayı katılamayan velilerin yapılanları destekleyen ifadelerde bulunduğu; ayn eğitim bölgesinde bulunan anaokullarının yönetici ve öğretmenlerinin çalışmalara katıldı̆ğ; hiçbir zorunluluk olmamasina rağmen projenin değerlendirilmesine yönelik değerlendirme formlarının, açık defterin ve süreç içinde istenen projeye yönelik mektupların oldukça fazla sayıda kişi tarafindan desteklendiği görülmüş̧ür.

$\mathrm{Bu}$ sonuçlardan hareketle farkındalık gelişimi çalışması olarak planlanan ve uygulanan projenin genel anlamda amacina ulaştığı, davranış değişikliği açısından bakıldığında değerlendirmeye ve bilgi toplamaya yönelik yapılan çalışmalardan toplanan verilerden hareketle katılımcilarda farkındalık yaratıldığı söylenebilir.

Ancak projenin gerekçesi olarak sunulan çocukluğun yok olması, çocukluğun anlaşılmaması sorununun çözülmesi söz konusu değildir. $\mathrm{Bu}$ projenin şöyle bir katkısı olabilir: Anaokulu'nda yapılan çalışma model olarak ele alınıp okul öncesi kurumlarından başlayarak tüm eğitim kurumlarında benzer çalışmaların yapılıp bu konuda bir bilinç oluşturulması ve bu bilincin toplumun değişik katmanlarına yaygınlaştırılması sağlanabilir.

\section{Kaynaklar}

Adıgüzel, H.Ö. (1994). Eğitimde Yeni Bir Yöntem ve Disiplin: Yaratıcı Drama 1985-1995 Yazılar. Ankara: Natürel Yayınevi.

Hamurcu, H., ve Ekinci, D. (2004). Reggio Emilia yaklaşımında teknoloji kullanımı. Çoluk Çocuk Dergisi, 37, 1, 16.

Okvuran, A. (1995). Çağdaş insan yaratmada yaratıcı drama eğitiminin önemi ve empatik eğilim düzeylerine etkisi. Ankara Üniversitesi Eğitim Bilimleri Fakültesi Dergisi. 1, 1, 186.

Öz, İ. (2003). Eleştirmeyin yargılamayın. Çoluk Çocuk Dergisi. 27, 18.

San, İ.(1989). Yaratıcı Drama - Eğitsel Boyutlar. Yaratıc1 Drama 1985 -1995 Yazılar. Editör: H. Ömer Adigüzel .(s.81-90). Ankara: Natürel Yayınevi.

Şatır, S. (1996). Özel Tevfik Fikret Lisesi ögrencilerinin akademik başarılarıyla ilgili anne - baba davranısları ve akademik başartyı artırmaya Yönelik anne-baba gereksinimlerinin belirlenmesi. ayınlanmamış Yüksek Lisans Tezi, Ankara: Ankara Üniversitesi.

Üstündağ, T. (2002).Yaratıcı Drama Öğretmenimin Günlüğü. Ankara: Pegem A Yayıncılık, 


\section{EK 1:}

\section{Çalışmanın Takvimi:}

Projenin okul personeline anlatılması

Projenin okul velilerine anlatılması

Bilgi, Duygu, Düşünce Paylaşım Toplantıları

Prof. Dr. Belma Atik Tuğrul, "Oyun ve Öğrenme"

Alp Boydak, "Öğrenme Stilleri ve Bireysel

Farkl111klar"

Prof. Hasan Pekmezci, "Yaratıcılık ve Resim"

Prof. Dr. Hamil Nazik, "Çocukluktan Büyüklüğe Tüketim"

Prof. Dr. Gelengül Haktanır, "Çocukluktan Büyüklüğe Özgüven"

Nalan Olgun, "Ben Nerede Hata Yaptım?"

Piknik ve proje genel değerlendirme toplantısı

Drama çalışmalarından oluşturulan bir seçkinin gösterilmesi

EK 2: Yaratıcı Drama Atölyelerinden Üç Oturumun İçeriği

1.Oturum:

Konu: Bilgi, duygu, düşünce paylaşım toplantılarının değerlendirilmesi (Yaratıcı drama çalışmalarına giriş ) oturumunun içeriği

Süre: 3 saat

Araç -gereç: CD çalar, Harem II CD'si, renkli fon kartonları, tahta kalemleri.

\section{Kazanımlar:}

Ön hazırlık toplantıları ile ilgili değerlendirmeyi yazılı ve sözlü olarak yapar.

Grup üyelerini tanır.

Grupla iletişim kurar.

Grupla etkileşimi sağlar.

"Söz Sırası Bizde" konu başlığı ile duyurulan toplantı, bilgi duygu ve düşünce paylaşım toplantılarının değerlendirilmesi ve yaratıcı dramaya küçük bir giriş yapmak amacıyla serbest oturum biçiminde gerçekleştirilmiştir.

Hazırlık - Isınma Çalışmaları:

1. Etkinlik*: Lider "Merhaba Arkadaşlar yaklaşık iki aydır süren beraberliğimizin yaratıcı drama bölümüne bugün küçük bir giriş yapalım istiyoruz. Önce bir tanışma oyunu ile başlayalım” der. Bir çember oluşturulur. Mümkün olduğunca en az tanıdıklarının yanında çemberdeki yerlerini almaları söylenir. Herkesin sağında ve solunda bulunan arkadaşının ismini öğrenmesi istenir. Araç olarak bebeğin kullanılacağ1, bebeğin sağa ya da sola doğru elden ele verileceği, verilirken de veren kişinin ismini söylemesi gerektiği anlatılır. İstenildiğinde bebeğin gidiş yönünün değiştirilebileceği, ancak bunun üst üste sadece iki kez yapılabileceği, oyuna tek bebekle başlanıp, oyun içersinde bebek sayısının artırılacağı söylenir. Oyunun en önemli noktasının bebeklerin elde bekletilmemesi ve düşürülmemesi gerektiği belirtilir. .

$\mathrm{Bu}$ kez bebeği verenin kendi ismini değil de, verdiği kişinin ismini söylemesi ile gerçekleştirilir (Oyun, bir süre oynanınca grup üyelerinin çemberde bulundukları yerlerin değiştirilerek ve bebek sayısı artırılıp, azaltılarak dört beş kez tekrarlanır).

2. Etkinlik*: Büyük bir çember oluşturulur. İçlerinden birinin gönüllü olarak oyuna başlayacağ 1 belirtilerek gönüllü seçilir. Gönüllü olanın çemberde en az tanıdığı birine doğru işaret ederek gitmesi, giderken de ismini tekrar etmesi istenir. Gittiği kişinin yanına geldiğinde onun eline vurarak yerine geçmesi söylenir. Eline vurulan kişi aynı biçimde ismini tekrar ederek yeni birine gider. Oyun bu biçimde tüm grup üyeleri oynayıncaya kadar sürdürülür.

$\mathrm{Bu}$ kez giden kişinin kendi ismini değil, gittiği kişinin ismini söylemesi biçiminde oynanır. $\mathrm{Bu}$ aşamada gruba mümkün olduğunca ismini yeni öğrendikleri kişilere gitmeleri konusunda hatırlatma yapılır. Oyunun sonunda tüm grubun ismini saymak isteyen olup olmadığı sorulur. Dört beş kişiye firsat verilerek isimler bir kez daha gözden geçirilir.

*Birinci ve ikinci etkinlik H.Ömer Adigüzel'in atölyesinden alınmıştır.

3.Etkinlik (Ev sahibi Kiracı Oyunu)*: Üçerli gruplar oluşturulur. İki kişi iki eliyle tutuşarak evi, bir kişide onların ortasına geçerek kiracı oluşturacak biçimde pozisyonlarını almaları sağlanır. Oluşturulan üçlü grupların her bir tarafından rahatça geçilebilecek 
biçimde mekandaki pozisyonlarını almaları söylenir. Tüm kiracılar evlerine yerleşip, bir kişinin (ebe- evsiz kiracı) ortada kalacağı biçimde düzenleme yapılır. El çırpıp "değiş̧" komutu verildiğinde evi oluşturanların merkeze bakan ellerini açarak kiracının evden çıkmasını sağlamaları söylenir. Tüm kiracılar ev değiştirirken ortadaki ebenin boş evlerden birine gireceği, ortada kalan kişinin yeni ebe olacağ söylenir. Oyun bir süre oynandıktan sonra ikinci aşamasına geçilir.

"Değiş " komutu yerine "içten değiş" komutu verildiğinde merkeze bakan eller açllarak, "dıştan değiş" komutu verildiğinde kenarlara bakan eller açılarak kiracıların ev değiştirmesi sağlanır.

Her iki komutun yanında "hepsi birden" komutu eklenir. "hepsi birden" komutu verildiğinde ev sahipleri ve kiracılar hepsi yer değiştirerek yeni bir üçlü oluştururlar. Yine ortada kalan ebe yani ev arayan kiracı olarak oyuna devam edilir.

*Oyunun birinci aşaması Ali Öztürk'ün atölyesinden, ikinci aşaması H.Ömer Adıgüzel'in atölyesinden alınmış, üçüncü aşama ise iki aşamadan esinlenerek üretilmiştir.

3. Etkinlik: Birlikte yaş ile ilgili bir sayı doğrusu oluşturulacağı söylenir. Sayı doğrusunun çalışma alanındaki yeri, nereden başlayıp, nerede bittiği gösterilir. Yaşlarına göre sayı doğrusundaki yerlerini almaları istenir. Yerlerini doğru olarak bulabilmeleri için birbirlerine doğum tarihlerini söylemeleri gerektiği hatırlatılır.

Gruba bir önceki çalı̧̧madaki sayı doğrusunda hissettikleri yaşa göre yerlerini almaları söylenir. Sayı doğrusunun başlangıcı 0 yaş, sonunun ise grup tarafından belirleneceği söylenir. Herkes yerini aldıktan sonra, yanında bulunanlarla niye o yaşta hissettiklerini paylaşmaları istenir.

Sayı doğrusunun başından başlayarak hissettikleri yaşları yakın olanların aynı grupta olmalarını sağlayacak biçimde 7 ayrı grup oluşturulur.

Grupların isimlerini birbirlerine söyleyerek bir kez daha tanışmaları istenir. Tanışma bitince müziğin sesine göre grup arkadaşlarından en uzak pozisyonda dans etmeleri söylenir. Müzik durduğunda grup arkadaşlarıyla buluşarak duvarda asılı olan kartonlardan birine gidip kartonda yazılı olan ifade ya da soru hakkında düşündüklerini hızla yazmaları söylenir. Kartonlarda yazılı ifade ve sorulan soruların bu akşamki çalışmanın yanı sıra yedi haftalık sürecini gözden geçirmelerini sağlayacak biçimde düzenlendiği belirtilir. Düşüncelerini yazarken bunu göz önüne almaları istenir. Müzik başladığında yeniden dans etmeye devam edilir.

Duvarda as1lı olan kartonlara;

1-Yedi haftanın sonunda cepte ne var?

2-Sorgulanan paradigmalar

3-Ne umuyordunuz? Ne buldunuz?

4- Eksik olan neydi?

5- Projeden kalan üç kavram

6-Çocuk değişiminde olan bitenler

7- Herhangi bir değeriniz değişti mi?

8- Ya şimdi, sizde kalan duygu? yazılır.

Gruplara, bütün kartonlara yazacak kadar süre tanınarak çalışma tamamlanır.

Değerlendirme: Gruplar en son yazdıkları kartonun yanında bekler. Her gruptan bir temsilci yazılanları okur, duygu ve düşüncelerini grupla paylaşır.

\section{OTURUM}

\section{Kazanımlar:}

Grup üyeleri ile etkileşimi sağlar.

İkili çalışmalarda güven duygusunu geliştirmeye kararl111k gösterir.

Bireysel özellikleri ile duyu çalışmaları arasındaki ilişkileri kavrar.

Kendini başkasının yerine koyar.

Toplumsal yaşamdaki gözlem gücünü geliştirir.

Araç gereç: Fon Kartonu, A4 çizgisiz kağıt, tahta kalemi, keçeli kalemler, pastel boya

Hazırık / Isınma Çalışmaları:

1. Etkinlik*: Gruptan ikili eş olmaları istenir. Aralarında bir A bir B olacak biçimde karar vermeleri söylenir. Eşler birbirine kollarından temas edecek 
biçimde pozisyonlarını alır. A hareketi belirleyendir. A ne yaparsa B kol temasını kopartmadan onu takip eder. A'ların B'lerin can güvenliğinden sorumlu olduğu belirtilerek çalışma başlatılır. Farklı devinimleri ve hızları deneyebilecekleri hatırlatılır.

Aynı çalışma B'lerin hareketi belirleyen ve aktif olan rolünü üstlenmesiyle tekrarlanır (*Ulrike Jungmair'in atölyesinden alınmıştır.).

2. Etkinlik*: Beşerli gruplar oluşturulur. Grupların birer lider belirlemesi istenir. Diğer dört kişinin liderlerinin vücudundan bir noktayı kendileri için seçmeleri bunu kimseye söylememeleri belirtilir. Kendileri için nokta belirlerken liderlerini rahatsız etmeyecek biçimde olması gerektiği hatırlatılır. Liderin çalışma alanında istediği gibi hareket edebileceği, grup üyelerinin ise seçtikleri noktaya göz temasıyla $30 \mathrm{~cm}$. uzaklığı koruyarak liderlerini takip etmeleri istenir. Grup liderine farklı h1z ve devinimleri denemesi önerilir. Çalışma için yeterli süre verilir. Sonra grup üyelerinin sırasıyla liderlik görevinin üstlenmesiyle çalışma tekrarlanır (*Luciana Iogna'nın atölyesinden alınmıştır. ).

3. Etkinlik: Gruptan bugüne kadar en az eş olduğu biriyle ikili eş olması istenir. Eşlerin ortak bir ses ya da yansılama bulması, aralarından birinin bu sesi çıkarması için karar vermeleri söylenir. Eşlerin birbirlerinden olabilecek en uzak noktaya gitmeleri söylenir. Hazır olduklarında gözlerini kapatmaları söylenir. Gözlerini hiç açmadan eşinin sesini takip ederek buluşmaları istenir. Herkes eşini bulunca yeni bir ses belirleyip, rol değiştirerek çalışma tekrarlanır.

4. Etkinlik*: Gruba alfabedeki tüm harfleri bedenleriyle yazmaları söylenir. $\mathrm{Bu}$ çalışma için yeterli süre verildikten sonra, yazamadıkları harf olup olmadı̆̆ 1 sorulur. Yazılamayan harf varsa gruptan yardımla bu harflerin nasıl yazılabileceği gözden geçirilir (*Ali Öztürk’ün atölyesinden alınmıştır.).

5. Etkinlik: Küçük kağıtlara beşer tane özgüven, çocuk, öğrenme kelimeleri yazarak katlanır. Katlanan kağıtlar çalışma alanının ortasına bırakılır. Grubun bu kağıtlardan birer tane alması istenir. Kağıdında aynı kelime yazılı olanların buluşmaları söylenir. Gruplar buluşunca kağıtlarında yazılı olan kelimeleri bedenleriyle grup olarak yazmaları söylenir.

Çalışmalar izlendikten sonra oyun, yaratıcılık ve tüketim kelimelerinden her biri birer gruba verilerek bunları da bedenleriyle yazmaları söylenir.

6. Etkinlik: Gruplara bedenleriyle yazdıkları iki kelimeyi ayrı ayrı kullanarak çağrışım zinciriyle yeni kelimeler yazmaları söylenir.

7. Etkinlik: Gruplara bu kelimeleri kullanarak sloganlar yazmaları söylenir. Sloganlarını yazarken başlangıçtan beri kullanılan anahtar kelimeleri dikkate almaları hatırlatılır.

\section{Canlandırma}

Gruba yazdikları sloganları da kullanarak bir reklam filmi hazırlamaları istenir. Reklam filminin bir öyküsü, kısa müziği ve sloganın yer alacağ bölümünün olması gerektiği belirtilir. Yeterli hazırlık süresinden sonra grupların canlandırmaları izlenir.

\section{Değerlendirme}

Gruba değerlendirme çalışmasının süreç içinde aralıklarla yapıldığı, ortaya çıkan çağrışım kelimelerinin, sloganların ve canlandırmaların içeriklerinin değerlendirme olarak kabul edileceği söylenir.

\section{OTURUM}

\section{Kazanımlar}

Dikkatini kişi, nesne, durum vd. üzerinde yoğunlaştırır.

Rol oynamalara ve doğaçlamalara katılmaktan zevk alır.

Yaratıcı dramayla ilgili bilgi birikimini günlük yaşamda kullanmaya kararlılık gösterir.

Anıların yaratıcı dramadaki önemini kavrar.

Kendini başkasının yerine koyar.

Toplumsal yaşamdaki gözlem gücünü geliştirir.

Araç gereç: Şapka

\section{Hazırlık/ Isınma çalışmaları:}

1.Etkinlik: Çalışma alanında serbest yürümeleri söylenir. Bir süre sonra asker, yaşlı kadın, köylü, Japon, öğretmen - öğrenci, anne/baba -çocuk, iki 
sevgili, izci, parkta karşılaşan çocuk, dede/nine çocuk, iki yaşlı adam şapkalarıyla selamlaşmalarını sağlayacak biçimde yönerge verilir.

2.Etkinlik*: Liderini Takip Et Oyunu: Gruptan bir gönüllü seçilir. Seçilen kişinin başına bir şapka takılır. Şapkalı kişi ne yaparsa grup onun yaptığının aynısını yapar. İsteyen şapkayı alarak liderliği üstlenebilir. Oyun grubun hepsinin liderliği üstlenmesi tamamlanınca bitirilir (*Tülay Üstündağ'ın atölyesinden alınmıştır. ).

3.Etkinlik: Gruptan ayakta büyük bir çember olması istenir. Sırasıyla "çocuk, genç, yaşlı, çocuk, genç, yaşlı" diye saymaları söylenir. Çocuk, genç ve yaşlı gruplarının buluşmaları sağlanır. Üç grubun kendi içlerinde mümkün olduğunca birbirleriyle çok temas edecek biçimde bir form belirlemeleri istenir. Bunun için yeterli süre tanınır. Grupların amaçlarının oluşturdukları formu bozmadan diğer iki grubun arasından geçmek olduğu ifade edilir. Bu oyunda herkesin hem kendi hem de diğer arkadaşlarının bedensel güvenliğinden sorumlu olduğu ayrıca belirtilir. İki grup arasından en fazla geçen grup oyunu kazanır.

4. Etkinlik: Gruba çember biçiminde yere oturmaları söylenir. Bir gönüllü belirlenir. Gönüllü çemberin ortasına gelerek istediği bir eylemi, işi, durumu söz kullanmadan canlandırmaya başlar. Bir başka gönüllü gelinceye kadar bu eyleme devam eder. Ortaya gelen ikinci kişi birinci kişiye "Ne yapiyorsun?"diye sorar. Birinci "Görmüyor musun? ..yapiyorum" der. Ancak yaptığ farklı bir şey söyler. Örneğin çamaşır yıkıyorsa, bale yapıyorum der. Bir başkası ortaya gelinceye kadar, ortadaki kişi bir öncekinin söylediği işi yapmaya devam eder. Aynı diyalog tekrarlanır. "Ne yapıyorsun? " , "Görmüyor musun, .................yapıyorum.” Örneğin bale yapıyorsa televizyon izliyorum der ve yerine oturur. Oyun grup üyeleri en az birer kez ortaya gelinceye kadar sürdürülür.

\section{Canlandırma}

5.Etkinlik: Beşerli gruplar oluşturulur. Grupların yan yana durarak birinci kişinin 5 yaşı, ikinci kişinin 15 yaşı, üçüncü kişinin 30 yaşı dördüncü kişinin 45 yaşı, beşinci kişinin 60 yaşı verilen durumlara göre kısaca canlandırmaları istenir. Canlandırmaları yaparken yaşlar arası kopukluk olmamasına, uygun geçişler yapılmasına dikkat çekilir. Sırasıyla torba taşıma, şarkı söyleme, en mutlu an, en kızgın an, en sevdiği şey vb. gibi durumlar verilerek ve her durumla ilgili yeterli hazırlık süresi verilerek canlandırmalar izlenir.

6. Etkinlik: Bir gönüllü seçilir. Seçilen kişinin 60 yaşlarını geçkin, şu anda yalnız yaşayan birisi olduğu anlatılır. $\mathrm{Bu}$ yaşamdan bir kareyi gönüllünün canlandırması istenir. Gruptan bu kişiye bir isim belirlemeleri istenir (Gönüllü olan katılımcının adı Ayşe olduğu için grup "Ayşe teyze" ismini uygun buldu). Daha sonra aşağıdaki yönergeleri hazırlık süresi verilmeden grubun canlandırması ya da yerine getirmesi istenir.

-Gruptan Ayşe teyzenin şu anda içinden geçenleri bir cümleyle söylemeleri istenir.

-Gruba Ayşe teyzenin evindeki eşyaları canlandırmaları söylenir. Katılımcılar ev ortamındaki yerini alır. Omzuna dokunulan kişinin girdiği eşya rolüyle bir cümle söylemesi istenir.

- Grupla Ayșe teyzenin hayatında kimlerin olabileceği üzerine konuşulur (Evlatlarının olduğu ancak onunla ilgilenmediği sonucuna ulaş1lır).

- Onu mutlu etmek için ne yapılabileceği üzerine tartış1ır (Sürpriz bir doğum günü partisi hazırlamaya karar verilir).

- Üç grup oluşturulur. Birinci grup teyzenin evini, ikinci grup doğum gününe gelen konukları, üçüncü grup doğum günü pastasını ve diğer aksesuarları canlandırır.

Gruba teyzenin bugünkü yaşantısı hakkında ortalama düzeyde bilgi sahibi olunduğu, bir önceki çalışmada oluşturulan gruplarla yeniden buluşulması söylenir. Birinci grubun Ayşe teyzenin 5 yaşından, ikinci grubun 15 yaşından, üçüncü grubun 30 
yaşından, dördüncü grubun 45 yaşından, beşinci grubun 60 yaşından bir kesiti canlandırması istenir.

\section{Değerlendirme}

Lider: İlk haftadan itibaren dönüp baktığımızda, çocukluğu ve büyüklüğü anlamak projesinde yaklaşık dört aydır birlikteyiz. Bugün son çalışmamızı yapıyoruz. Çalışmaya ilişkin değerlendirmeye geçmeden önce genel bir açıklama yapmak istiyorum.
$\mathrm{Bu}$ projeden beklentilerimizi konuşmuştuk. Sizce ulaşabildik mi? Drama sürecinden sonra hangi sonuçlara ulaştık? Doğrular, yanlışlar? Grup lideri hakkında düşünceleriniz, önerileriniz ve eleştirileriniz neler? Bunları yazarak getirebilirseniz mutlu olurum. Şimdi bugünden kalan izler neler sırayla onları paylaşalım. 


\title{
Utilization of Creative Drama as a Teaching Method in Development for Awareness of being Mother and Father
}

\author{
Ö. Özlem GÖKBULUT* \\ National Education Ministry
}

The children who are the adults of tomorrow and the significant characters for community pass through a significant period in preschool since their development is rapid in this period and their personality is almost constructed. Having this period effectively has an effect on educating creative individuals and the construct of the community directly. For this, there is a need for understanding the child and the concept of childhood, the developmental characteristics of the child.

Although all the educational institutions pay attention and work hard to educate the children, it can be observed that some unapproved behaviors can be occurred in children and those behaviors can be lasted when a child becomes an adult. It was thought that the unapproved behaviors could have an impact on the basic systems like education, law, etc. of a country.

In this study, one of the active learning methods which is creative drama was used. Creative drama includes the implementations in which there is an integration of affective, psychomotor, and cognitive domains of the individuals and the learning is based on the individuals' experiences. Creative drama is a group activity and it comes from the previous learning experiences of the participants. The starting point of creative drama and the whole process are related to the accumulation of the

participation of the individuals and their experiences (Adıgüzel, 2003, s.2).

About the concept of understanding the childhood, it is necessary to improve the

*Ms, Preschool Teacher, E-mail: ooozlem@mynet.com awareness of the parents, the other adults in the environment of the children, and the social community of the children. Due to this fact, taking an individual as a starting point, the relationship between the group/groups in which the individual belongs and the society should be established. At this point, it was thought that the nature of creative drama concerns the phases from an individual to a group and from a group to the society. Hence, this method was considered to be helpful fort his study.

The target group was determined as the parents of 120 students who are in Gelincik Preschool (in Etimesgut District in Ankara), the teachers and other personel of this school, all parents, and the preservice kindergarden teachers. All the participants were volunteerly involved in this study.

This study consisted of two parts; first part can be named as preparation part in which the feelings and experiences of the participants were shared with the help of field experts. This part had 9 sessions. The second part is the implementation of creative drama activities taking 8 sessions (24 hours). According to the findings, it can be claimed that this study reached its purpose, the implementation occured an awareness in participants.

\section{Results, Discussion, and Suggestions}

When the purpose of this study was examined, it can be understood that the perception of the concept of the childhood and 
the communication between the school and the family were determined as a problem. For solving this problem, the main focus was on the concept of "understanding the childhood".

The prerequisite knowledge for understanding anything, any case, or anybody is knowing himself or herself for individuals. One of the aims of the meetings in which the participants' feelings and thoughts were shared was knowing himself or herself for individuals. The evaluation process indicated that this study achieved this purpose. Although the topic was understanding the concept of childhood, most of the participants explained the changes in theirselves, the experinces belonging to their lives. The participants reconsidered the relationship between their children, the correct behaviors, or their failures after the self evaluation part. They claimed honestly that by the help of this study they confronted with theirselves.

Though, it can be argued that these results are very contributive for this study, the main thing is to make a significant change in parents' behaviors. Based on the findings, it can be claimed that the study accomplished its purpose, it created an awareness about the concept of understanding the childhood in participants. However, it can not be expected from this study to solve the problem of not understanding of the childhood and the case of losing the childhood. From this study, it can be suggested that, similar research studies can be carried out in different educational institutions by modeling this study so that in the future there can be a common concius about this topic and this concious might be widespread in different segments of the society. 